\title{
Gerald John Pillay's prophetic role in the South African and New Zealand contexts
}

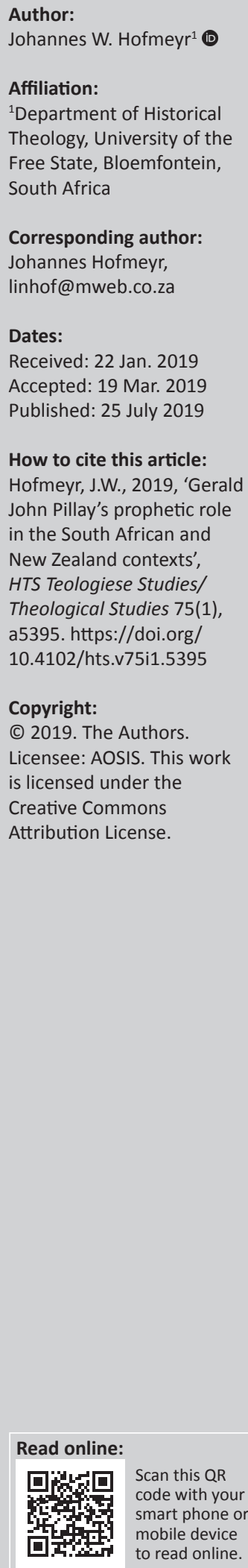

In this article, the question in focus is the church and Christianity's prophetic responsibility towards society, and how in the specific case of the South African-born theologian Gerald John Pillay, his prophetic voice should be characterised. The question is addressed as to whether he was an activist at the barricades or a soft-spoken intellectual in his views on society. After a brief discussion on his bio, the focus is on the phenomenon of being a prophet towards society. Then, the focus, largely based on a literature study, moves to Pillay's perspectives on the South African and New Zealand contexts, and then a discussion of some of Pillay's writings on being a prophetic voice follows. Finally, in the conclusion, his specific style and model of being a prophetic voice are analysed.

Keywords: Gerald Pillay; Role of a prophet; South Africa; New Zealand; Michel Welker; Albert Luthuli; Social justice.

\section{Introduction}

The question being addressed in this article focuses on the issue of the church and Christianity having a constant responsibility to be sensitively aware of developments in politics and society, and to continually raise a prophetic voice whenever necessary. Firstly, I will, in the following analysis of Gerald John Pillay's life and work primarily as a church historian, try, as objectively as possible, to examine and, secondly, analyse his involvement in and views on two southern hemisphere contexts where he lived and worked from the 1980s to the 2000s, namely, South Africa and New Zealand. I will largely use in this analysis, which is the first of its kind, a literature study together with being a participant observer so as to move towards some conclusions, without being one-sided about his contributions and being overly appreciative of him as a person. In all of this, my specific focus will be on his role as a theologian with regard to his prophetic witness in these societies.

Next to his relatively important role and contribution in the field of tertiary education, his most important contribution was indeed in the area of having a prophetic witness on issues related to social justice. It remains, then, to characterise the specific nature of his prophetic voice and judge whether it made any difference.

\section{Gerald Pillay: A brief bio}

Gerald Pillay was born in 1953 in Durban as a fourth-generation South African Indian Christian. He came from a family that had migrated in the middle of the 19th century from India to Natal. More than 150000 Indian migrants to Natal arrived between 1860 and 1911 as indentured labourers, and most of them spoke Tamil, Telugu and Hindi. Of these, nine in 10 (about 137 000) were Hindus, about 13000 were Muslims and just more than 2000 were Christians. Gerald Pillay and his eventual wife Nirmala grew up in South Africa under the system of apartheid. Although their parents, according to personal communications with the author, never tried to negatively influence or depress their children about the harshness and realities of the apartheid system, they could not ever agree with the discriminatory nature of the policy, and from both the families' sides a deep sense of justice was instilled in their children. They were people of dignity and sobriety, and were strongly influenced by the examples of Mahatma Gandhi and their religious convictions.

Gerald attended the Centenary Secondary School in Durban and eventually did a Bachelor of Arts at the University of Durban-Westville with Classical Hebrew, Hellenistic Greek and Philosophy.

Note: Christina Landman Festschrift, sub-edited by Wessel Bentley (University of South Africa) and Victor S. Molobi (University of South Africa). 
This university was specifically created under the apartheid system for the purpose of providing tertiary education to the Indian population in South Africa. Gerald then went on to obtain a Bachelor of Divinity. He further holds a Doctor of Theology (D Theol) degree from the University of Durban-Westville, and afterwards obtained a Doctor of Philosophy (D Phil) degree from Rhodes University in Grahamstown in 1983.

Gerald's involvement in the southern hemisphere is inseparable from his identity as a South African Indian, and his voice should be seen in the context of a disenfranchised minority group and as one of the prominent figures in bringing about intellectual change and transformation in the South African context. His parents and his family as highly civilised people were not activists at the barricades, but as committed Christians of Pentecostal background they expressed their voices in a soft, subtle but convincing way. According to personal discussions that was not only their constant approach in the old South Africa, but even now in the new South Africa.

\section{The challenges of being a prophet}

I have little doubt in my mind that Gerald Pillay in his views on society is very much a prophet of his times, though of a specific sort. He was never a radical or a front row social activist; on the contrary, he is indeed a soft-spoken person which is also reflected in his style as a public speaker: 'I still get just as nervous before I talk now as I did before the first time in South Africa'. He continues: 'I think this is a great thing because it stops me getting complacent and makes sure I give my all at every talk I give' (Pillay 2011:11). Gerald remains gentle but with strong convictions, outspoken in his thoughts on various injustices in society. Next to Gerald Pillay's other greatest contribution, namely, that of him being a great educator, I now wish to focus with some more detail on the phenomenon, that is, the nature of being a prophet.

The South African Pocket Oxford Dictionary defines a prophet as 'First a person who predicts the future, and secondly a person sent by God to teach people about his intentions' (SA Pocket Oxford Dictionary 2002:715). It is the latter half of the definition that applies to Gerald.

My overview of what it means to be a prophet is based not only on some biblical but also on sociological perspectives. I will briefly be relying on the useful discussion of 'prophet' by two authors, the US Princetonian Thomas W. Gillespie and the South African Estelle Dannhauser. They provide two important sources for this overview.

In 1994, a very valuable perspective on being a prophet was published by Thomas W. Gillespie, one of the former presidents of Princeton Theological Seminary. This book contains a noteworthy foreword written by Michel Welker, which sheds some light on what it means to be a prophet in our time. Welker claims that he had regarded the general notion of prophecy, 'especially of contemporary "prophecy"... to smack of pretentiousness, moral selfrighteousness, or even soothsaying' (Gillespie 1994:ix). Later, two things became clear to him:

First, classical prophecy oriented itself on the basis of complex, systematic interconnections of law and wisdom. Second, the great prophets were astute analysts and diagnosticians of the processes of social development and decay in their day. Taken together, classical prophecy combined substantive theology and substantive cultural and social criticism in ways that are, at least in principle, clear and comprehensible, even to us today. (p. ix)

Welker further explains that it has become clear to him that we should not content ourselves with understanding and interpreting the complex of 'the prophetic' as a phenomenon of past cultures. 'Proclamatory interaction is characterized both directly and indirectly as "prophetic speech"' (Gillespie 1994:ix).

Welker then refers to Thomas W. Gillespie's published doctoral dissertation, which attempts to explain how Paul understood 'Christian prophecy'. Using Paul's theology as a focus, Gillespie explores the broad spectrum of European and North American views of prophets. Gillespie's (1994) aim is to work out:

standards with regard to 'early Christian prophecy' that enable theology in general to recognize its task and obligation as well as its freedom and dignity. Theology demonstrates itself to be a prophetic power inasmuch as it aids in interpreting the 'inherent implications of the kerygma' (preaching) (JWH). (p. x)

Without going into any detail on different perspectives of Gillespie himself, his perspective on prophecy essentially boils down to the fact that the kerygma of the crucified Christ is the ground and subject of prophecy, which, in his opinion, consisted of the theological and ethical exposition of the gospel in the life situation of the church. All in all, it is clear that Gillespie believes that being the church itself implies being prophetic. There is a need to speak 'truth to power' and to realise that there is no peace without justice, and then with special reference to issues pertaining to social injustice, lack of integrity and corruption. Here one can refer to the exemplary thinking and writings of people like Dietrich Bonhoeffer, Martin Luther King Jnr, David Bosch and Nelson Mandela.

According to Dannhauser (2006), the sociologist Max Weber holds up a mirror of his discipline to reflect on the phenomenon of prophecy:

$\mathrm{I}[i] \mathrm{t}$ reveals a wide range of figures from various religions and cultures, all meeting the requirements that sociology sets for someone to qualify as a prophet. One of these prophetic figures is Jesus. He claims authority on the grounds of personal revelation and charisma and exerts his power through his personal gifts. (p. 360)

Weber in his thinking distinguishes between two types of prophets, namely, 'ethical prophets' and 'exemplary prophets'. 
The former preaches as one who has received a commission from God and demands obedience as an ethical duty, and the latter demonstrates the way to religious salvation by means of personal example. Villa-Vicencio adds to this: 'His [Weber's, $J W H]$ description of the social prophet reminds one of biblical and other prophetic traditions' (Villa-Vicencio 1988:187).

Dannhauser (2006) refers to N.T. Wright in his description of Jesus as a prophet. Wright concluded that Jesus was indeed a prophet, based on the biblical evidence of friend and foe and by the villagers who listened to him. According to Wright, Jesus' speech and actions had evoked for them and contemporised pictures stored in collective and individual memories of the traditional (Old Testament)(JWH) prophets while even surpassing it when he inaugurated the kingdom of Israel both with the welcome and the warning announced by the double-edged sword of his word (encompassing divine love and divine wrath) ... 'Jesus' praxis and worldview typify him as a prophet bearing an urgent eschatological message for Israel' (Dannhauser 2006:386).

I wish to state emphatically that the role of the prophet is indeed multidimensional. The prophet's role is to evaluate people's lives on a religious, moral, economic, social and, naturally, also a political level. But addressing social injustices is only one aspect of a prophet's role.

Naturally, much more can be said about the whole issue of being a prophet and how to deliver a prophetic witness within society, but space does not permit. I, however, at least wish to mention the following two sources for further research material. Firstly, Robert Vosloo has just published an article in In Luce Verbi (Vosloo 2019), where he focuses on 'Prophetic Witness in Weakness'. This article emphasises a theological engagement regarding the prophetic role of Christians in the public sphere in South Africa. Secondly, in a fairly recent collection of essays entitled Reformed Churches in South Africa and the Struggle for Justice (2013), edited by Mary-Anne Plaatjes-Van Huffel and Robert Vosloo, a whole subsection of the book is committed to the issue of remembering prominent South Africans and in this case specifically Reformed voices. Different prophetic figures and different prophetic approaches come into focus like Beyers Naude, Johan Heyns, David Bosch, Willie Jonker, Allan Boesak, Jaap Durand and Nico Smith. It is clear also from these reflections that the period especially between 1960 and 1990 was not only a dramatic, but also a traumatic period in South African church and theological history, in which also Gerald Pillay played his specific and humble part.

\section{Gerald John Pillay as a prophetic voice towards society in South Africa}

Gerald Pillay constantly strived towards integrity, honesty, hope and social justice. This especially applied to his personal life as well as his academic career in South Africa. Gerald served for some years as an associate professor in the Department of Church History at Unisa. Prior to this he was a lecturer and a senior lecturer at the University of DurbanWestville. He eventually became a full professor at Unisa, the first non-white head of the Department of Theology and the first non-white vice dean of the Faculty of Theology.

In the early 1990s, which was a period of dramatic change in South Africa, he was asked to lead a university-wide process to promote equity and excellence to address the issue of how to include those who had been excluded under apartheid on the basis of race. 'Having been a victim of the old apartheid system and being the only Indian professor, I was drawn into questions of renewal ...' (Ward 2008:2).

Responding to a question in the period when Mandela came to power about his role at the forefront of a 'revolution' in education as the only Indian professor at Unisa (where some people had great dreams for Gerald to be part of the top leadership), Gerald Pillay (2011) said:

One of my tasks was to help in the transformation of the university to meet the new democracy. The difficult thing was to be in between an almost fearful group wanting to hold onto privilege, and another impatient group, wanting change as soon as possible. I think that was part of those years, one had to keep peace and keep both sides talking, to be the intermediary between these different groups. One of the things of the struggle was a sense of furtive self-interest, for some to protect and others to extend. (p. 6)

But fortunately as Pillay implies with people like Mandela around, 'they embodied a changing, transcendent period ... who transcended self interest. Who can forget what they've done' (Pillay 2011:7).

Gerald Pillay (2011) was experiencing, as a prophet in the desert (similar to one of the people he admired, the very early prophet against apartheid, Prof. Ben J Marais) the desert starting to bloom:

People from different parts of society, the disenfranchised were drawn into new opportunities. Empowering and creating opportunities for those who had been shut out and then finding the right role models for those young black people that was what that period achieved really. (p. 6)

The sad reality, however, was that the democratisation process in the emerging South Africa needed urgently to redress the situation black South Africans were in and Indian people found that they were not of pressing concern - not white enough in the previous regime and apparently not disadvantaged enough in the new one. The new, colour blind, South Africa would take a while to emerge. Therefore, it can be plainly stated that Pillay's decision to eventually accept an academic and influential position as foundation professor and head of the Department of Theology at Otago University in Dunedin in New Zealand was not because of a chicken run mentality, but merely realising that at that stage his potential and talents (even as a possible Vice Chancellor of Unisa) were not properly realised, or were because of his Indian background, not in demand. 
Gerald Pillay was never, in a negative sense, an activist: his revolt was different. As a reporter of the UK-based newspaper The Guardian quoted him as saying:

$\mathrm{O}[\mathrm{O}]$ ne of the powerful ways that people like us could articulate the liberation story was through theology, because in South Africa theology was a living discipline, not an ivorytower one. (Ward 2008:2)

It is interesting to note that Gerald once suggested that theologians, especially in South Africa, were regardless of colour and race, some of the strongest, most vociferous and critical voices among all academicians against the apartheid system in South Africa. In a memorable interview he said as much:

\begin{abstract}
A few law professors and sociologists were brave souls and spoke up against the apartheid system. I think (however) (JWH) theologians more than any other discipline were probably the most critical ... Unlike any other discipline they were able to speak very bravely to the situation, the human predicament in Africa. People have used religion for unholy purposes, but growing up in South Africa I saw how faith can actually be part of the struggle. I don't know how the historians will record it but it was faith that gave reconciliation a chance in South Africa. In our world we need to discover a meaningful place for faith. (Pillay 2011:5)
\end{abstract}

Gerald was no stranger to conflict even in the church. He was not ashamed of being a prophet from the pulpit of the church. He had, in the course of his life and career, many involvements in different ecclesiastical contexts. He participated in activities such as the 'Colleges and Universities of the Anglican Communion (CUAC)'. Its India Chapter, for instance, met in November 2005 in the town of Karakonam where Gerald was the special guest. He all along, in spite of various stressful events in his life, never lost his belief that education at its core was also about the pursuit of truth. There was always a strong link between his theology, his faith and his role as educator. On this occasion, also in India, he indeed explored the need to articulate faith through an education that shapes life and moulds character. He stressed that the only way to make a mark as Christian colleges and universities is to stand for quality and care of individuals. Pillay (2005) added:

Institutions could perform better together than standing alone in fulfilling their mission. Financial independence through innovative resource-generation and pooling of resources and building trusting relationships would take the institutions to greater heights. He concluded by quoting Nelson Mandela who went into prison as a young angry man but came out totally transformed as a proof of transformative education. (p. 2)

\section{Gerald John Pillay as a prophetic voice towards society in New Zealand}

It was by 1997 that Gerald moved to New Zealand to become the foundation professor and head of the Department of Theology and Religious Studies at Otago University in Dunedin, far down on the south eastern coastline of
New Zealand's South Island. The taste of the New Zealand society, free of racial tension, was somewhat too tempting for Gerald to resist.

In New Zealand, the theological seminary at Otago University was, to a large extent, in turmoil because theological positions had become heavily politicised and dialogue largely broke down. This made it impossible for the staff of the seminary to work together. The University of Otago decided to pull out of the seminary and establish a Department of Theology (Davidson 1997:178-179). They wanted a rigorous academic approach, research and scholarship, and wished to be free from the problems of the seminary.

At a difficult time Gerald was appointed as the foundation chair of the first Department of Theology in Australasia ever. It was a bold move for the university because New Zealand is highly secular, and also because of some resistance at the university about this. Gerald attempted to establish a Department of Theology that would be trusted by the full spectrum of Protestant churches and Catholics. Trust had to be built with the various Christian communities while ensuring that the scholars and scholarship would be first class. This department remained one of the top and leading departments in the whole of New Zealand even after Gerald left for the United Kingdom, also according to the national research assessment exercise.

The initial call to New Zealand was an opportunity for him to return to his own discipline and academic work. He also now had the responsibility to bring theology back from a seminary context to a secular institution like Otago University. Quite soon, however, in 1998, he became head of the university's liberal arts school and once again part of the university administration.

Although I never worked or lived with Gerald in the New Zealand context, I remained in close contact with him. Through the eyes of other colleagues and friends in New Zealand, I managed to construct a fairly good picture of Gerald's comings and goings in that context. I can assert without fear of contradictions that he fully accepted New Zealand as his new home and took up New Zealand citizenship, of which he is still very proud.

In the New Zealand context, Gerald found that the role of Christianity in society was very different from South Africa. In this new context, he had to wrestle with the idea that Christianity was not a living, driving, critical force, but rather a diminishing influence in an increasingly secularised society. Pillay also felt that Christianity has become a minority voice in a secularised world, and in many ways it is becoming a marginalised voice. It is a matter of not only living in a secular context, but also living in a context that is sceptical about religion and cynical about Christianity. The option of a spiritualised passivity for social justice is definitely not an option as much as social activism, which is cut from a context of worship and confession of faith. It then 
seems as if theology has, in some ways, lost its nerve. In that case social justice can easily become a substitute for a living faith tradition.

Gerald's role as a senior academic and as an educational leader is thoroughly informed by a strong and clear Christian conviction. In a paper delivered at the 'Otago Tertiary Chaplains', he referred to the Christians' prophetic role and his understanding of the Sermon on the Mount. He rejected the idea that faith and working for justice were sometimes at odds, condemning this as a fragmented theological vision. According to Pillay, in the early church, the connection between faith and proclamation and the standing up for righteousness was self-evident and inseparable. However, for us 'moderns' some 200 years under the shadow of the Enlightenment, an eroding process of secularisation, and internal ecclesiastical divisiveness, the possibility of any wholeness of theological vision has become greatly diminished. The churches, especially the Protestant branch, have proliferated. 'To generalise therefore, about the Church or Christianity as if these are definable entities is simplistic and not very helpful' (Pillay 1999:1).

Although he did not specifically refer to the New Zealand context, it was that context and the problem of the increasing secularisation of society that highlighted for him the importance of a prophetic voice within the educational context. In his reflections on the Sermon on the Mount, he observed:

The need in our time is again to discover the power of truth and love over violence and carnality, the way of grace that goes beyond mere self-interest, and the meaning of redemptive suffering which is at the heart of the Christian gospel (Pillay 1999:9)

It requires the development of a kind of creative action that Christ our Lord describes in three different examples coming from the Sermon on the Mount:

If anyone strikes you on the right cheek, turn to him the other also. If anyone takes away your coat give him your cloak as well, and if anyone forces you to go one mile, then go the second mile. (Pillay 1999:8)

According to Pillay, this was difficult to understand in the South African context where he grew up. It almost seemed to him as if Christianity was some kind of effete religion which responded to evil with passivity and stoical silence. Later he discovered the true meaning and power of that sermon.

In his Greencoat Forum Lecture at the Initiatives of Change Centre in London delivered on 22 November 2008, Gerald's ideas about the role of a university in society were given a voice. This was developed through his experiences, first, at a racially segregated university in Durban, then at a distant learning institution, Unisa in Pretoria, which reached more than 100000 students of all hues and backgrounds, and then his experience with the experiment of introducing theology to the old and secular Otago University in Dunedin. In this lecture he addressed the issue: 'Challenges facing higher education: can a university be a catalyst for social change?' He explored the theme of universities being the 'critic and conscience of society'. Pillay (2008) reminded the audience that:

Universities in the West began with the church and theology and that it was Islamic Scholars who helped the rediscovery of Aristotle in the West, since they had preserved his writings in Arabic. (p. 2)

His main message was about truth being confined to an 'idealised, contrived objectivity' (Pillay 2008:2).

Gerald's life, time and exposure to the New Zealand context and his work at Otago University were an excellent preparation for his work in the United Kingdom, where he is likely to retire. New Zealand was a good bridging experience from his rather painful experiences in South Africa, where the dynamic role of the church and education prepared him for the founding of the Department of Theology at Otago University, and eventually the role as Vice Chancellor and Rector of Liverpool Hope University, the only ecumenical university in Europe. When Gerald went to Liverpool Hope College, the college was giving out University of Liverpool degrees. Gerald had the task of moving it from a university college to a university while ensuring that it took its place among universities in Europe because of its unique nature as the only ecumenical university in Europe. This took a tremendous amount of trust building with Protestants, Catholics and secular stakeholders. The university is open to all, produces first-class research and has achieved a gold standard in teaching. In the meantime, however, it remains true to its Christian foundation.

When Gerald moved to Liverpool Hope University, he continued, like in New Zealand, to focus on social justice, harmony and conflict resolution also in the Liverpool context. Although not being directly part of this article's focus, it is interesting to refer to the following: in 2004, Liverpool Hope University, for instance, established a Centre for War and Peace Studies. In 2007, Liverpool Hope University approached Archbishop Desmond Tutu to give his name to the Centre in Liverpool motivated by the great work he did with the Truth and Reconciliation Commission in South Africa. In celebration of the naming of the Centre, Desmond Tutu gave an address in the Liverpool Metropolitan Cathedral on 26 June 2007, entitled 'Ours is a Moral Universe'. The Centre sees itself as a platform of constructive and interdisciplinary engagement between academics and practitioners who work on issues related to peace, war and conflict from a variety of perspectives. It also tries to shed light on the multidimensional challenges that are faced by militarism and deeply divided societies and on societies emerging from conflict.

Gerald regularly returns to the theme of the prophetic role of the university in society. In the concluding chapter of The foundation of hope: Turning dreams into reality, Gerald 
explains his vision of 'Hope (University)(JWH) in the Future' that the three remaining areas of university competence are those of teaching and learning, research and community service. He then adds that the last is sometimes referred to as the social or public responsibility of the university or its "ethical vision"” (Pillay 2003:13).

\section{Gerald John Pillay as the author of some prophetic publications}

Gerald's publications especially during the South African phase, which possibly was his most productive time in terms of theological writing, can largely be put into three categories. Those are independent books published by him, co-edited books in collaboration with others and periodical articles in different academic journals. In this overview, our focus is, however, largely on the prophetic voice, which Gerald reflected in his publications. We will, therefore, primarily discuss his publications in which he reflects on the issues of being a prophetic witness to society.

In terms of stand-alone or independent book publications by Gerald, the most important one is possibly Voices of liberation: Albert Luthuli (Pillay 1993). Albert Luthuli received the Nobel Peace Prize in 1960. He was the first of four South Africans, namely, Desmond Tutu, F.W. de Klerk and Nelson Mandela, to receive this highly coveted award.

This book was updated for a second edition in 2012. Gerald was and remains a great admirer of those who sacrificed much in their struggles against the old South African systems and who articulated a clear message of liberation. His respect was so much the greater when that figure represented the fight for non-violent change. This is especially true when Gerald published this book containing a summary of Luthuli's life story and some very valuable writings, documents and speeches of and about Albert Luthuli's involvement in the South African struggle.

The following are the very striking aspects in the introduction of the book: firstly, Gerald's analysis of the major influences in Luthuli's life. Deeply in solidarity with the rural African (the Zulu) (JWH), he attempted to interpret his Christianity contextually and, like Mahatma Gandhi had done earlier in South Africa, and only a few years before in India, Luthuli attempted to practise some of the key injunctions of the 'Sermon on the Mount'. Pillay then quotes Luthuli, who in 1958 said: 'My view is that if you hate your oppressor and not his evil deeds, you show yourself as insufficiently developed morally' (Pillay 1993:28). Luthuli's sociopolitical work, as described by Pillay, was an extension of his Christianity. The American Board Mission's secretary in South Africa described him as 'a responsible Christian who has sought faithfully to serve his people'. His political speeches are full of Christian ideas and metaphors. Luthuli preached a Christian ethos relevant to the predicament of his people by combining their faith with their sociopolitical quest. He sought a nation that would be built on 'godly principles'. It was because he was a Christian that he felt he 'could not obey laws which affronted his essential dignity' (Pillay 1993:28).

Finally, Pillay (1993) uses an excerpt from Alan Paton's tribute to Luthuli at the latter's funeral for his evaluation of Albert Luthuli's contribution in the South African struggle:

There are some people who think that his life was a failure. Some will think he went too far and some that he did not go far enough. But that is not the real story of his life. The real story of his life is the story of his fortitude. If you win in life, you are a successful man. If you lose you are an unsuccessful man. But if you go on whether you win or lose, then you have something more than success or failure. You keep your own soul. In one way, Luthuli lost the world but kept his own soul ... although he was silenced, history will make his voice speak again, that powerful brave voice that spoke for those who could not speak. (p. 33)

In 1991, Gerald and I co-edited Perspectives on Church History: an Introduction for South African Readers. We could co-operate on this publication, two people from different backgrounds, and on different sides of the colour line on a history text because we were united in our view of how best to approach the hard task of meandering through the painful history of the peoples who make up this land and for whom that history was still defining and real. The foreword spelt out our position:

... history in South Africa has often been a tool in the hand of ideologues. $[T]$ the (five) authors cooperating to produce this publication dealt at length with the hermeneutical nature of historical study. (Pillay \& Hofmeyr 1991:i)

We went further and stated:
... the study of church history is fundamentally dialogue with others who, at different times in diverse contexts, sought to understand the Christian message in a relevant and meaningful way. The contextualisation of theology, which has in our times in South Africa become an important issue, is not new.
Contextualisation, the meaningful and mutual encounter of the Gospel and its context, is endemic to the theological process. Not all the past understandings are consistent. Neither has every attempt at contextualisation in the past become part of authoritative tradition, nor is every tradition equally binding on everyone.

Therefore, 'church history may be defined as the history of the contextualisations of Christian understanding' (Pillay \& Hofmeyr 1991:i).

We went on to co-operate and co-edit another publication, entitled A History of Christianity in South Africa, published in 1994. The intention here was to fill the need for a new theological perspective on the history of Christianity in South Africa rather than being another social history of Christianity. As work on the book progressed, which, in different ways, was an attempt to already start decolonising South African church history by focusing on religion in precolonial South Africa: 
it became increasingly clear that South African Christianity and the concomitant ecclesiastical developments and counter developments were directly influenced by the changing sociopolitical circumstances. The social implications of the prevailing socio-political order often determined when, where and how even the most indigenous forms of Christianity emerged. (Hofmeyr \& Pillay 1994:i)

One example is the rise of the African initiated churches in South Africa: factors such as culture, cosmology, ethos, ethnicity and economic circumstances all played a role.

It is very clear to me that Gerald also, as a prophetic voice, remained true both to his inner convictions and to his professional training as a church historian. He shows very great insight and maturity as a church historian with a clear theological interpretation and mind. In an article in Studia Historiae Ecclesiasticae (Pillay 1988), he takes up some very clear positions. He feels, for instance, strongly about the fact that in the course of time 'the theological significance of the church's history has been neglected. It has often been overlooked that the church historian is in fact examining Christian responses to Scripture' (Pillay 1988:86). He also feels strongly about the fact that history is interpretation, not merely the establishing of 'testable propositions' about the past. 'Against the philosophical backdrop of the works of Lessing, Troeltsch, Dilthey and Gadamer amongst many others ... there has emerged within theological discussions too a growing concern with hermeneutics'. With a clear concern for hermeneutics, he could say:

If the work of the church historian is not always contributing to the ongoing quest for theological meaning in the world, for the world, church history is not more than the cataloguing of information on Christianity. But that is not history. (Pillay 1988:88)

Through the sometimes unconscious predisposed and rigged hermeneutical process, the 'church historian attempts to understand that body of inherited Christian truth which consciously and unconsciously influences all theological discussion in the present'. Referring to the South African situation, he states that 'not only must the context and the text be placed in dynamic and critical tension but also the differing contextual perspectives in society must be placed in critical encounter with each other' (Pillay 1988:90).

Gerald's theological position, together with his historical position, becomes clear when his articles published especially in Studia Historiae Ecclesiasticae, the journal of the Church History Society of Southern Africa of which Christina Landman is the current editor, are examined. Besides the reference to the article above, I will now specifically single out another of his articles here.

In December 1995, an important article with a prophetic slant was published in Studia Historiae Ecclesiasticae under the title 'Church, State and Christian Pluralism in South Africa: a Historical Overview'. The main theme of this piece was about the danger of certainty - when intrinsic Christian ambiguity completely disappears:

The interactions between churches and governments in South Africa have been neither the same nor uniform for any period of time. The chief reason for any lack of uniformity has been the ambivalent position in which Christians often found themselves while attempting to live out their faith within their society; the ambiguity that underpinned their 'being in the world but not of the world'. Only where the Christian witness was completely subsumed by the political or vice versa did the ambivalence seemingly diminish or even disappear. (Pillay 1988:90)

Pillay illustrates his point by considering the role of missionaries as a specific case in point. 'The ambiguity of the social or public witness of the churches may best be illustrated by the historical manifestation of Christian mission in the 19th century'. He refers to a certain N. Majeke's somewhat one-sided perspective on the role of missionaries also in South Africa:

The missionaries have been severely criticized and sometimes rightly so for their part in the process of domination; from being couriers of colonization and capitalism to being misguided altruists and idealists. (Pillay 1995:81)

According to Pillay, this criticism helps to illustrate that the relation between missionaries all over the world and those in government was neither simple nor uncontroversial. In the South African context (referring to the missiologist W.A. Saayman), there were many thousands of missionaries across the world, who illustrated at least four patterns of relations with government. He also adds some examples within each of these approaches and then with specific reference to the South African situation:

those who supported governments uncritically as long as they were given the freedom to undertake their missions [collaboration] (the Dutch Reformed churches together with some Evangelical and Pentecostal churches).

Those who withdrew as much as it was possible from any contact with the government or its agencies [withdrawal] (some other Pentecostal churches, Pietist groups, several African Initiated Churches and some Baptist churches).

The largest group remained ambivalent about the government with which they dealt: they needed the protection the government offered and acknowledged the rights of government even if they did not always agree with its policies or methods of governance [ambivalence] (some groupings within the Anglican and Catholic churches together with many of the other established churches and a large African Initiated Church such as the Zion Christian Church).

Those who remained a thorn in the flesh of government: they openly criticized its policies (especially its attitude to the indigenous population) and used every opportunity to publish their criticisms [opposition] (this group largely consisted of individuals and they were also known for their prophetic role. They included people like Phillip, Colenso, Mokone, Reeves, Huddleston, Marais, Naude, Hurley, Boesak, Bosch and Tutu). (Pillay 1995:82)

Pillay, in this overview, is taking the 'long view' (la longue durée), and states that the church struggle during the apartheid 
era was not another or a new phase in church or state relations. In his opinion, it was merely a 50-year interruption in the process of the acceptance of religious pluralism that already began in the 1870s and 1880s (Pillay 1995:82).

\section{Gerald John Pillay's prophetic views on two Southern Hemisphere contexts: Some conclusions}

In this article, the question in focus is the church and Christianity's responsibility towards society, and how in the case of the South African-born theologian Gerald John Pillay, his prophetic voice can be characterised.

The question will be discussed as to whether he was an activist at the barricades or a soft-spoken intellectual or even an armchair critic in his views on society.

He is a person of high intelligence, and is widely respected for this. He is, furthermore, a person with a soft-spoken, calm but strong personality with strong and clear views on issues, especially of the first order. He is not a pushover in terms of his opinions. He is a committed prophet of the Kingdom of God with a clear voice on especially injustices in society. He feels strongly about the prophetic role of the Christian and also of the church at large. As already indicated, when David Ward of The Guardian (London) interviewed Gerald, he stated that for Pillay South African theology was very much a truly living discipline, and therefore he was no armchair critic of a specific political system. And ' $\mathrm{C}[\mathrm{C}]$ hanging his philosopher's cap for the garb of a clown momentarily', he jests, 'p $[P]$ hilosophers often didn't say boo to a goose'. Gerald is not only a competent historian, but, according to a friend, Gerald most probably was a theologian of the Word and moved by the Spirit. He could re-imagine the world by faith towards a more hopeful future in the living 'here and now' in ways a philosopher might not. That is eventually what a 'living theology' implies.

On the contrary, he did not prove not to be an activist standing at the barricades in raising his prophetic voice. In some ways, one even expected more from Pillay as a prophet in South Africa, in the sense of a stronger activist approach. The lack thereof can, however, most probably be ascribed to his Pentecostal background, where religion and politics were in his formative years not well combined or mixed. Similar to what Allan Paton said about Albert Luthuli, some may think that Pillay went too far and some that he did not go far enough. That is, however, not the real story of his life because his real story is the story of his fortitude.

Gerald Pillay was very much aware of the different contexts in which he functioned, and he was very clear on the view that his field of specialisation, that is, church history, is the history of the contextualisations of Christian understanding. His role as a prophet did, indeed, change over time because of the changes in the different contexts. His prophetic witness therefore changed from the issue of social injustice in South Africa to harmony in New Zealand, and eventually to conflict resolution in the Liverpool context.

I believe he should be placed in the line of other South African prophets, who worked for a more just and reconciled society. More interestingly, it is not only a matter of being seen in this way, but some of these figures were also the greatest intellectual and personal influences in his life: I can think of many such as Mahatma Gandhi, Albert Luthuli, Nelson Mandela, Alan Paton, Desmond Tutu, Ben Marais, David Bosch, Wilfred Napier, Calvin Cook, Caesar Molebatse, Willem Krige, Pippin Oosthuizen and John de Gruchy. To say exactly who influenced Gerald's thoughts and thinking the most is, in many ways, quite difficult. I believe, however, having read most of his publications and having listened to and being in his presence over an extended period of time, that the strongest influences came from especially people like Mahatma Gandhi, Albert Luthuli, Alan Paton, Desmond Tutu, Pippin Oosthuizen and David Bosch. Finally, I can say with conviction that Gerald Pillay was at least one of the most well-established and clearest intellectual prophetic voices of the late 20th and early 21st centuries in the Southern Hemisphere. He definitely made a difference and then especially in the intellectual discourse as a type of intermediary on societal matters by influencing other thinkers.

Gerald as the son of different continents never lost ties with South Africa and New Zealand. Pillay (2011) stated:

one is indelibly touched by every part of one's life. South Africa formed me: without South Africa I wouldn't be who I am, it was as enriching as it was hurtful. New Zealand is a lovely place where my race didn't matter and we settled there. (p. 7)

And Liverpool Hope University was a chance to do something new and different.

In a way one wishes that his prophetic voice can still continue to reverberate through these continents and especially the countries in which he was deeply involved. It is especially in South Africa that his type of deeply founded and calm prophetic voice is in dire need. It applies especially to the issues of social justice, corruption, state capture and the crisis in the South African educational system. There is, for instance in South Africa, a very great need for the rebuilding of a proper educational culture in primary, secondary and even tertiary contexts. But besides that, Gerald and his prophetic voice are examples and models of how to remain morally steadfast in a critical and challenging context.

\section{Acknowledgement Competing interest}

The author declares that no competing interest exists.

\section{Author contributions}

I declare that I am the sole author of this research article. 


\section{Funding}

This research received no specific grant from any funding agency in the public, commercial, or not-for-profit sectors.

\section{Data availability statement}

Data sharing is not applicable to this article as no new data were created or analysed in this study.

\section{Disclaimer}

The views and opinions expressed in this article are those of the authors and do not necessarily reflect the official policy or position of any affiliated agency of the authors.

\section{Ethical consideration}

This article followed all ethical standards for carrying out research without direct contact with human or animal subjects.

\section{References}

Dannhauser, E.H., 2006, 'Jesus the Prophet: Maps and memories', Unpublished PhD dissertation, University of Pretoria, Pretoria.

Davidson, A.K., 1997, Christianity in Aotearoa: A History of Church and Society in New Zealand, The New Zealand Education for Ministry Board, Wellington.
Gillespie, T.W., 1994, The first Theologians: A study in early Christian Prophecy, WB Eerdmans, Grand Rapids, MI.

Hofmeyr, J.W. \& Pillay, G.J. (eds.), 1994, A history of Christianity in South Africa, HAUM Tertiary, Pretoria.

Pillay, G.J., 1988, 'The on-going historical quest for meaning and relevance', Studia Historiae Ecclesiasticae 14(1), 85-91.

Pillay, G.J., 1993, Voices of liberation: Albert Lut(h)uli, HSRC Press, Pretoria.

Pillay, G.J., 1995, 'Church, State and Christian Pluralism in South Africa', Studia Historiae Ecclesiasticae 21(2), 71-86.

Pillay, G.J., 1999, Working for justice, Otago Tertiary Chaplains, viewed 12 November 2017, from http://www.otago.ac.nz/chaplain/resources/otago 017073.html.

Pillay, G.J., 2003, 'Hope in the future', in T.J. Elford (ed.), The foundation of hope: Turning dreams into reality, Liverpool University Press, Liverpool.

Pillay, G.J., 2005, 'Compass Points News', CUAC 8(2), 2, viewed 05 February 2018, from www.cuac.org.

Pillay, G.J., 2008, 'Greencoat Forum Lecture, Initiatives of Change Centre', in Universities should be the 'Conscience of Society', viewed 11 July 2008, from http://uk.iofc.org/universities.

Pillay, G.J., 2011, I think there is greater need than ever before, especially in the West for religious literacy, viewed 12 November 2017, from http://www.thesouthafrican. com/sa-power.

Pillay, G.J. \& Hofmeyr, J.W. (eds.), 1991, Perspectives on Church History: An introduction for South African readers, De Jager-HAUM, Pretoria.

Plaatjes-Van Huffel, M.A. \& Vosloo, R., 2013, Reformed Churches in South Africa and the struggle for justice, Sun Press, Stellenbosch.

South African Pocket Oxford Dictionary, 2002, 3rd edn., Oxford University Press, Cape Town.

Villa-Vicencio, C., 1988 Trapped in Apartheid: A Socio-Theological History of the English-speaking Churches, David Philip, Cape Town.

Vosloo, R.R., 2019, 'Prophetic witness in weakness', In Luce Verbi 53(4), 1-6.

Ward, D., 2008, 'Gerald Pillay: Hope and faith', The Guardian, January 28, 2008, p. 11. 